\title{
ANTEMORTEM DIAGNOSIS OF HUMAN RABIES IN A VETERINARIAN INFECTED WHEN HANDLING A HERBIVORE IN MINAS GERAIS, BRAZIL
}

Mariana Gontijo de BRITO(1), Talita Leal CHAMONE(1), Fernando José da SILVA(2), Marcelo Yohito WADA(3), Alexandre Braga de MIRANDA(4), Juliana Galera CASTILHO(5), Maria Luiza CARRIERI(5), Ivanete KOTAIT(5) \& Francisco Leopoldo LEMOS (1)

\begin{abstract}
SUMMARY
The Ministry of Health's National Human Rabies Control Program advocates pre-exposure prophylaxis (PEP) for professionals involved with animals that are at risk of contracting rabies. We report an antemortem and postmortem diagnosis of rabies in a veterinarian who became infected when handling herbivores with rabies. The antemortem diagnosis was carried out with a saliva sample and a biopsy of hair follicles using molecular biology techniques, while the postmortem diagnosis used a brain sample and conventional techniques. The veterinarian had collected samples to diagnose rabies in suspect herbivores (bovines and caprines) that were subsequently confirmed to be positive in laboratory tests. After onset of classic rabies symptoms, saliva and hair follicles were collected and used for antemortem diagnostic tests and found to be positive by RT-PCR. Genetic sequencing showed that the infection was caused by variant 3 (Desmodus rotundus), a finding confirmed by tests on the brain sample. It is essential that professionals who are at risk of infection by the rabies virus undergo pre-exposure prophylaxis. This study also confirms that molecular biology techniques were used successfully for antemortem diagnosis and therefore not only allow therapeutic methods to be developed, but also enable the source of infection in human rabies cases to be identified accurately and quickly.
\end{abstract}

KEYWORDS: Human rabies; Non-bite rabies exposure; Antemortem and postmortem diagnosis; Molecular biology.

\section{INTRODUCTION}

Rabies is an acute, progressive, fatal disease caused by a neurotropic RNA virus from the family Rhabdoviridae, genus Lyssavirus. Mammals from the orders Carnivora and Chiroptera are the main reservoirs ${ }^{13}$. According to WHO estimates, around 55,000 people throughout the world die from the disease every year, $99 \%$ of whom are on the Asian and African continents ${ }^{16}$.

In Brazil, epidemiological investigations and laboratory diagnosis are essential to guide measures implemented as part of the National Human Rabies Control Program.

In Minas Gerais as well as Brazil as a whole, the incidence of human rabies transmitted by cats and dogs has been falling over the years. However, there has been a change in the epidemiological profile of the disease, and cases of human rabies transmitted by bats have been reported.

Although there was an increase in the number of samples sent for laboratory diagnosis of canine and feline rabies in Minas Gerais from 2000 to 2006, the number of confirmed cases of rabies in these species fell during the same period. The number of human rabies cases transmitted by dogs also fell, and the last case was reported in 2003. In 2004 and 2005, one case of human rabies was reported each year; epidemiological and laboratory investigation of both cases confirmed the disease had been transmitted by hematophagous bats.

The progressive increase in the incidence of bovine rabies in Minas Gerais is evidence of the change in the epidemiological profile of rabies, which is reflected in the increasing importance of transmission by hematophagous bats and other wild animals ${ }^{1,2,14}$.

We describe a case of human rabies in 2006 in the municipality of São João del Rei, Minas Gerais, involving a health professional (a veterinarian) who had not previously been immunized against rabies and who refused a post-exposure regimen after he came into contact with a herbivore that subsequently died and was confirmed in laboratory tests to have been infected with the rabies virus.

\section{MATERIALS AND METHODS}

Epidemiological investigation and clinical data: The data were obtained from the National Information System for Notifiable Diseases (SINAN) and the patient's medical records. The epidemiological

(1) SES Health Surveillance Department/MG, Belo Horizonte, Av. Afonso Pena 2300, B. Funcionários, 30130-007 Belo Horizonte, MG, Brazil.

(2) São João Del Rei Regional Department of Health. Av. Amilcar Savassi S/N, Sericícola, 36200-494 São João Del Rei, MG, Brazil.

(3) Department of Health Surveillance/MS, Brasília/DF, SCS, quadra 04, bloco A, lote 67/97, 70304-000 Brasília/DF, Brazil.

(4) Eduardo de Menezes Hospital, Rua Dr. Cristiano Resende 2213B, Bom Sucesso, 30620-740 Belo Horizonte, MG, Brazil.

(5) The Pasteur Institute of São Paulo, Av. Paulista 393, Cerqueira Cesar, 01311-000 São Paulo, SP, Brazil.

Correspondence to: Ivanete Kotait, Instituto Pasteur, Av. Paulista 393, 01311-000 São Paulo, SP, Brasil. E-mail: ikotait@ pasteur.saude.sp.gov.br 


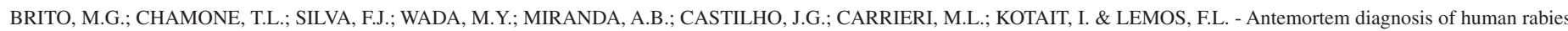
in a veterinarian infected when handling a herbivore in Minas Gerais, Brazil. Rev. Inst. Med. Trop. São Paulo, 53(1): 39-44, 2011.

investigation, which was carried out by a staff from the local Department of Agriculture, involved the patient's family and neighborhood.

On May 15, the Minas Gerais Department of Health was notified of a suspected rabies case in a patient admitted to Eduardo de Menezes Hospital, a reference hospital in the state for infectious and contagious diseases. The patient was a 27-year-old male from Campo das Vertentes, state of Minas Gerais, Brazil.

Onset of the disease occurred on May 7, 2006, with occipital headache and pain that radiated to the right side and was predominant in the upper limb, the area where the patient had probably come into contact with material from the infected herbivore. The signs evolved to include mental confusion and a reduced level of consciousness.

The patient was put in deep sedation induced with ketamine and midazolam, and antiviral drugs were administered (ribavirin and amantadine). After developing intense polyuria, hyponatremia and episodes of cardiac arrhythmia that were controlled with medication, he died on May 26, 2006, as a result of reentrant arrhythmias that were difficult to control, followed by cardiac arrest (Fig. 1).

\section{Laboratory diagnosis by RT-PCR and DNA sequencing}

RT-PCR: An approximately $1 \mathrm{~cm}^{2}$ sample of neck-skin biopsy and a saliva sample were collected from the patient before his death, and a brain sample was collected postmortem from the same patient.

Total RNA was extracted from the neck-skin sample (cut into small pieces with a scalpel), from the brain sample and from $300 \mu \mathrm{L}$ of saliva, using TRIzol® reagent (Invitrogen) according to the manufacturer's instructions. Aliquots of a "Challenge Virus Standard" (CVS) strain of fixed virus and water were used as positive and negative controls, respectively. RT-PCR was carried out with sense primer 504 (5' - TATACT CGAATCATGATGAATGGAGGTCGACT -3') and antisense primer 304 (5'-TTGACGAAGATCTTGCTCAT-3') for antemortem diagnosis and sense primer 21G (5'-ATGTAACACCTCTACAATG-3') and antisense primer 304 (TTGACGAAGATCTTGCTCAT) for postmortem diagnosis as previously described by MACEDO et al. $(2006)^{10}$.

The RT-PCR products (249 bp and 1478 bp for antemortem and postmortem diagnosis, respectively) were visualized under UV light after gel electrophoresis on $1 \%$ agarose gel containing ethidium bromide in TBE buffer.

DNA sequencing: The amplified DNA fragments were purified with the GFX ${ }^{\mathrm{TM}}$ PCR DNA and Gel Band Purification kit (GE Healthcare), visually quantified with a Low DNA Mass Ladder (Invitrogen) and sequenced using the BigDye ${ }^{\circledR}$ Terminator v3.1 Cycle Sequencing Kit (Applied Biosystems) with the sense and antisense primers according to the manufacturer's instructions. The reaction products were then resolved in an ABI-3130 automatic sequencer (Applied Biosystems ${ }^{\mathrm{TM}}$ ).

Phylogenetic analysis: For the antemortem diagnosis, a 249 bp region of the nucleoprotein $(\mathrm{N})$ gene located between nucleotides 1286 and 1533 of the Pasteur Virus (PV) (GenBank accession number M13215.1) was analyzed, while for the postmortem diagnosis a 1478 bp region of the $\mathrm{N}$ gene located between nucleotides 55 and 1533 of the $\mathrm{PV}$ virus was analyzed. First, the raw sequencing data were edited using CHROMAS version 2.24 software (Copyright $@$ 1998-2004 Technelysium Pty Ltd.), and the final consensus sequence for each sample (neck-skin, saliva and brain tissue) was aligned with homologous sequences in GenBank using the CLUSTAL/W method with the Bioedit program and submitted to BLASTn to confirm sequence identity ${ }^{7}$. The alignment was then used to build a neighbor-joining distance-based phylogenetic tree using the Kimura two-parameter correction model with 1,000 bootstrap replicates and the Mega 2.1 program ${ }^{8}$. The identities between the aligned sequences were calculated using the Bioedit program.

Direct immunofluorescence: This was carried out using a fluorescein-conjugated anti-rabies polyclonal antibody produced in hyperimmunized rabbits by the Pasteur Institute of São Paulo and slides prepared with impressions of brain tissue, as described by DEAN et al. (1996).

Viral isolation in mice: A suspension was prepared from the brain sample and inoculated intracerebrally in eight 21-day-old Swiss albino mice, according to the technique advocated by KOPROWSKI (1996) ${ }^{9}$

Antigenic typing by indirect immunofluorescence using monoclonal antibodies: Slides prepared with brain tissue from firstpassage mice were typed antigenically using a panel of monoclonal

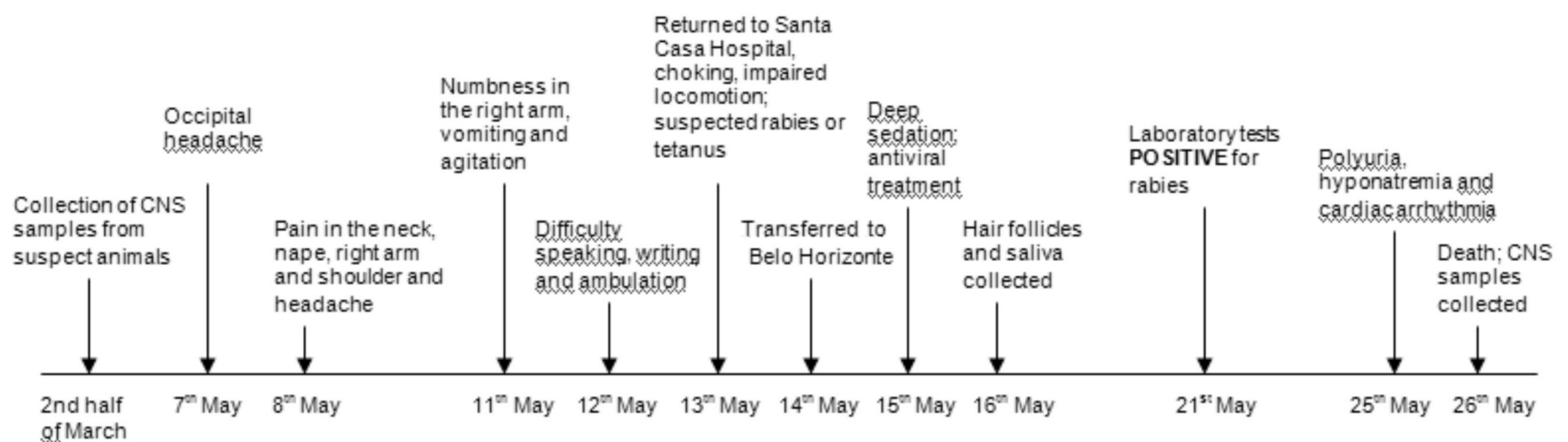

Fig. 1 - Timeline of the course of rabies in the patient, Minas Gerais, Brazil, 2009. 


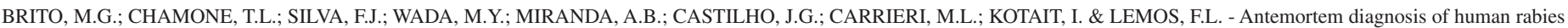
in a veterinarian infected when handling a herbivore in Minas Gerais, Brazil. Rev. Inst. Med. Trop. São Paulo, 53(1): 39-44, 2011.

antibodies provided by the Centers for Disease Control and Prevention (CDC), in Atlanta, USA, to characterize the variants isolated on the American continent ${ }^{6}$. Serological testing could not be carried out because serum samples were not collected at any stage of the disease.

\section{RESULTS}

Epidemiological investigation and clinical data: Exposure probably occurred in March 2006 in the town of Prados, state of Minas Gerais, Brazil, and it was suggested that the virus might have been transmitted by an animal from the caprine species that the patient, a veterinarian, was attending to. The municipality where he had been working had had several cases of rabies in herbivores, all confirmed by laboratory tests at the Minas Gerais Institute of Agriculture (IMA). It was not possible, however, to identify the species of herbivore involved in the infection or the exact date and time that the infection occurred. The veterinarian worked on various farms in the municipalities of Prados, Coronel Xavier Chaves, Tiradentes and São João del Rei. In the same month there were four cases of rabies in herbivores (three in bovines and one in a caprine) in the municipality of Prados. There were also two confirmed cases in bovines in other municipalities in the São João del Rei Regional Health Department district; one of these was in Madre de Deus de Minas, and the other in Entre Rios de Minas. According to information provided by the IMA (personal information), there had been clinical cases of rabies in herbivores in various municipalities in the region, although these had been neither reported nor confirmed by laboratory tests.

The patient did not report having been attacked by bats, dogs or other animals and had never had either pre-exposure antirabies vaccinations or antirabies prophylaxis after contact with suspect herbivores. He did not use any type of personal protection equipment to collect samples from animals suspected of rabies.

\section{Laboratory diagnosis}

RT-PCR, DNA sequencing and phylogenetic analysis: The neckskin biopsy and saliva samples were positive by RT-PCR, yielding a 249 bp fragment, and the brain sample, which was also positive by RT-PCR, yielded a $1478 \mathrm{bp}$ fragment. No amplified products were detected in the negative control, and no extra band was detected. A total of 249 and 1478 nucleotides located between nucleotides $1286 / 1533$ and 55/1533 of the rabies virus genome, respectively, were analyzed using the PV strain as a reference. Final sequences of 106 and 1290 nucleotides of the $\mathrm{N}$-gene region between nucleotides 1314-1420 and 130-1420 of the PV virus were obtained for antemortem and postmortem diagnosis, respectively.

The topology of the phylogenetic tree (106 bp - antemortem diagnosis) showed four distinct clusters (Fig. 2): 1 - samples associated

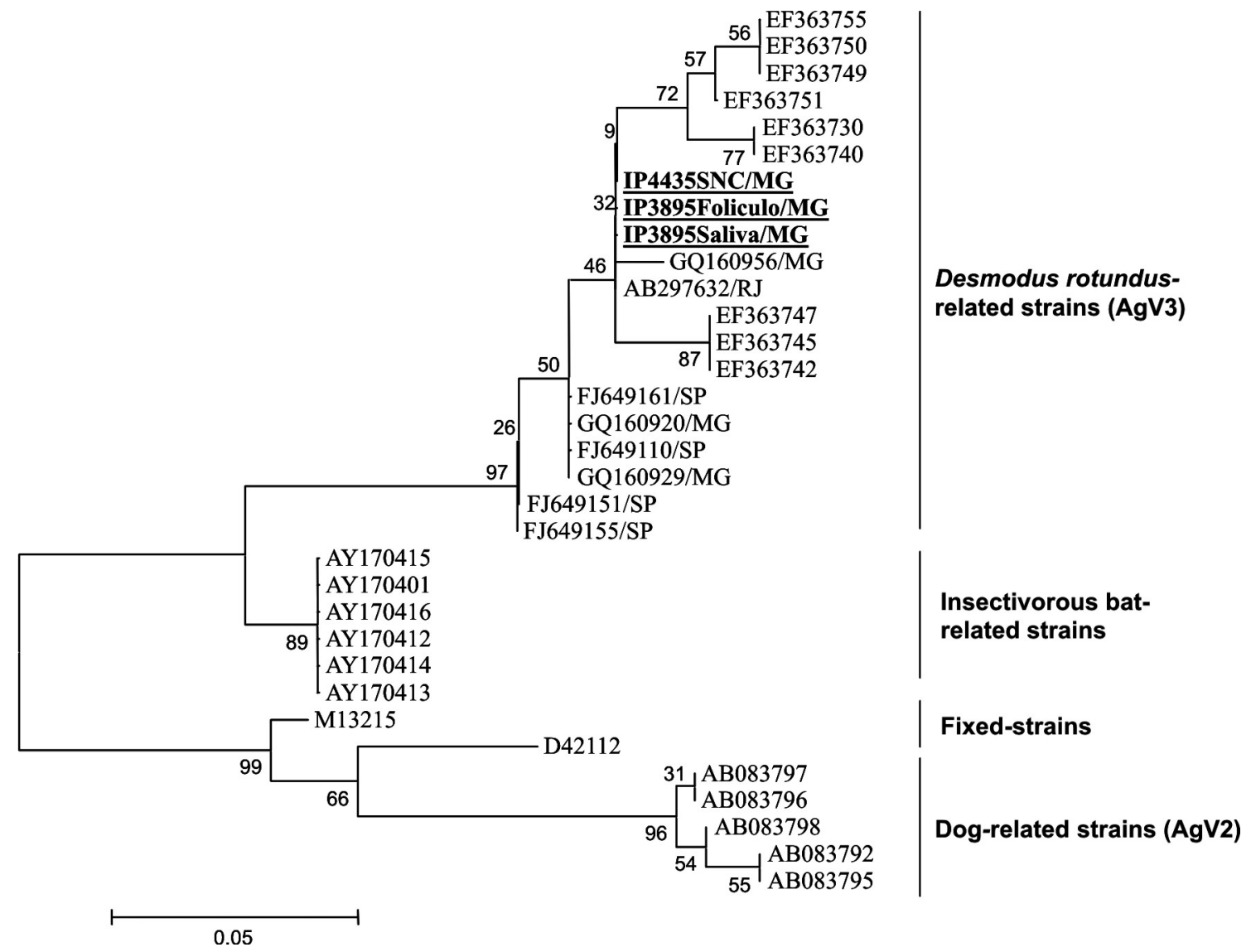

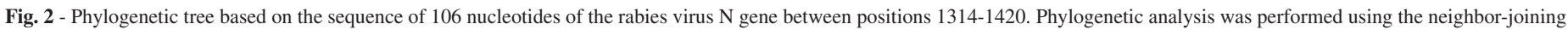

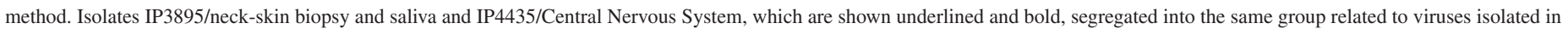
hematophagous bats (Desmodus rotundus). The names of the samples in the tree refer to the GenBank accession numbers. 
BRITO, M.G.; CHAMONE, T.L.; SILVA, F.J.; WADA, M.Y.; MIRANDA, A.B.; CASTILHO, J.G.; CARRIERI, M.L.; KOTAIT, I. \& LEMOS, F.L. - Antemortem diagnosis of human rabies in a veterinarian infected when handling a herbivore in Minas Gerais, Brazil. Rev. Inst. Med. Trop. São Paulo, 53(1): 39-44, 2011.
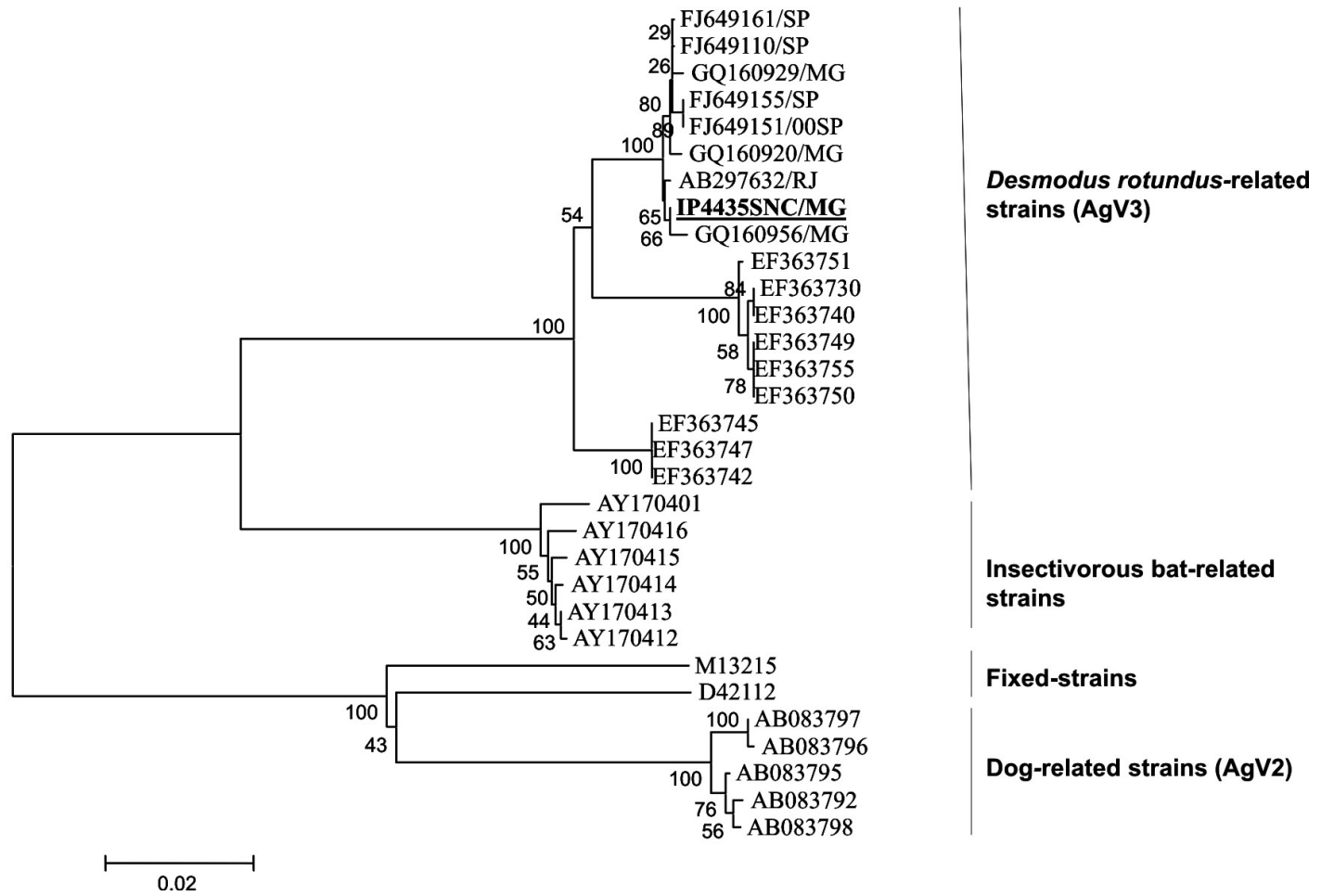

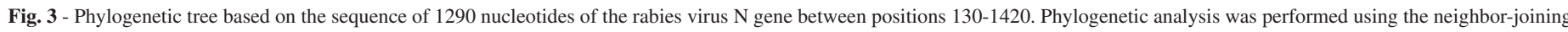

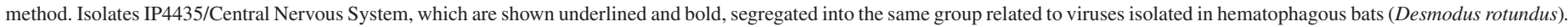
The names of the samples in the tree refer to the GenBank accession numbers.

with hematophagous bats; 2 - samples associated with insectivorous bats; 3 - fixed samples; and 4 - samples associated with dogs.

Isolates IP3895 (neck-skin biopsy and saliva) and IP4435 (brain tissue) had $100 \%$ identity between them and segregated into a cluster formed by Desmodus rotundus isolates (bootstrap $=97$ ) from different regions of Brazil.

The topology of the phylogenetic tree (1290 bp - postmortem diagnosis) showed four distinct clusters (Fig. 3): 1 - associated with hematophagous bats; 2 - samples associated with insectivorous bats; 3 - fixed samples; and 4 - samples associated with dogs.

Isolate IP4435 (brain tissue) segregated into a cluster formed by Desmodus rotundus isolates (bootstrap $=100$ ) from different regions of Brazil.

Direct immunofluorescence: The slides were positive for the rabies antigen and the test was specific as no fluorescence was detected in the negative control.

Viral isolation in mice: The virus was isolated 10 days after inoculation of the mice.

Antigenic typing by indirect immunofluorescence using monoclonal antibodies: The reactivity pattern of the virus isolated from mice was compatible with that of variant 3 (AgV3), which is characteristic of the variant isolated from the hematophagous bat Desmodus rotundus, the main transmitter of rabies to herbivores.

\section{DISCUSSION}

With the increasing number of rabies cases in economically important animals, veterinarians or animal owners who handle these animals are at risk of contracting the disease since, irrespective of the species they belong to, infected animals eliminate the virus in their saliva during the pre-symptomatic and symptomatic phases ${ }^{3,5}$.

The Brazilian Ministry of Health Regulations for the Prophylaxis of Human Rabies recommend that individuals whose work exposes them to a risk of contracting rabies through contact with animals receive pre-exposure prophylaxis (PEP) and that those who have been exposed to animals with rabies receive post-exposure vaccination. In the case described here, the patient had not received PEP and had refused postexposure prophylaxis; this lack of immunological response led to his death $^{11}$.

Exposure probably occurred in March 2006 in the town of Prados, Minas Gerais, and the likely transmitter was a caprine that the veterinarian had been attending to. He had been working in the municipality of Prados, where there had been cases of animal rabies that had been confirmed in laboratory tests. However, the type of herbivore and exact place and time the infection occurred could not be determined with any degree of certainty as the patient had been working on various farms in the region.

As there was no record of the veterinarian having been bitten by bovines or caprines, exposure must have occurred when he was handling 


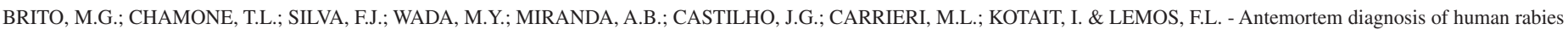
in a veterinarian infected when handling a herbivore in Minas Gerais, Brazil. Rev. Inst. Med. Trop. São Paulo, 53(1): 39-44, 2011.

infected animals and came into contact with their saliva. The records show that liquids were administered orally to an infected animal in March. Contamination may also have occurred when a brain sample was being collected to be sent to the diagnostic laboratory for confirmation of suspected rabies. On both occasions the veterinarian failed to use personal protection equipment (PPE).

The present study describes the first human rabies case successfully diagnosed antemortem using molecular biology methods standardized by MACEDO et al. $(2006)^{10}$. The recent cases of rabies in Wisconsin, USA, and Recife, Brazil, in which patients survived when coma was induced and antiviral drugs were used, show that molecular methods are important tools for the early identification of human rabies and allow the Milwaukee ${ }^{15}$ or Recife ${ }^{12}$ protocols to be used.

Antigenic and genetic studies identified variant 3 - compatible with the variant found in the hematophagous bat Desmodus rotundus, the main transmitter of rabies in herbivores - in the saliva, hair follicles and brain tissue of the patient, confirming the data from the epidemiological investigation.

Efforts should be made by federal, state and municipal health and agricultural institutions as well as by universities to make people aware that the antirabies vaccine is strongly recommended for veterinarians and can help avoid cases like that described here.

We conclude that:

1. In our study the molecular biology methods currently available for antemortem laboratory diagnosis of rabies were used successfully. These allow therapeutic methods for the treatment of human rabies to be developed and maintained and the source of infection in rabies cases to be accurately identified before death, so that a more thorough epidemiological investigation can be undertaken.

2. It is essential that professionals who are at risk of infection by the rabies virus undergo PEP to ensure they are appropriately immunized for field activities such as the collection of samples to diagnose animal rabies.

3. Individuals exposed to suspect animals, particularly those that have been confirmed rabies-positive in laboratory diagnostic tests, must undergo post-exposure prophylaxis as advocated by the Brazilian Ministry of Health and World Health Organization.

4. Educational programs focusing on PEP and appropriate serological follow-up should be developed with universities and veterinary services.

\section{RESUMO}

\section{Diagnóstico ante-mortem de raiva humana em médico veterinário infectado por manipulação de herbívoro, Minas Gerais, Brasil}

O Programa Nacional de Controle da Raiva Humana do Ministério da Saúde preconiza o esquema profilático pré-exposição (PEP) para profissionais envolvidos com animais expostos ao risco de contraírem raiva. $\mathrm{O}$ presente trabalho relata o diagnóstico de raiva (ante e postmortem) em veterinário infectado por manipulação de herbívoros raivosos. O diagnóstico laboratorial ante-mortem foi efetuado a partir da saliva e biópsia de folículo piloso, utilizando técnicas de biologia molecular e o post-mortem a partir do tecido cerebral e de técnicas convencionais. O médico veterinário coletou amostras para diagnóstico de raiva em herbívoros (bovinos e caprinos) suspeitos que, posteriormente, foram confirmados positivos em laboratório. Após a apresentação dos sintomas clássicos de raiva e realizadas as provas de diagnóstico antemortem com saliva e folículo piloso, ambas as amostras apresentaram resultados positivos pelo nested-RT-PCR. O sequenciamento genético revelou que a infecção se deu pela variante 3 do Desmodus rotundus, resultados estes confirmados com a amostra do cérebro. É indispensável que profissionais expostos ao risco de infecção pelo vírus da raiva realizem a profilaxia pré-exposição. Ressalta-se, também, que as técnicas de biologia molecular apresentaram bons resultados para a realização de diagnóstico ante-mortem, propiciando o desenvolvimento de métodos terapêuticos, e determinando com precisão e rapidez a fonte de infecção dos casos de raiva humana.

\section{REFERENCES}

1. Barbosa AD, Silva JA, Moreira EC, Meneses JNC, Magalhães DF, Menezes FL et al. Distribuição espacial e temporal da raiva canina e felina em Minas Gerais, 2000 a 2006. Arq Bras Med Vet Zoot. 2008;60:837-42.

2. Brito MG, Chamone TL. Ações de controle da raiva canina e felina no estado de Minas Gerais, 1999-2002. Bol Epidemiol. 2002;6:1-8.

3. Carrieri ML, Peixoto ZM, Paciência ML, Kotait I, Germano, PM. Laboratory diagnosis of equine rabies and its implications for human postexposure prophylaxis. J Virol Methods. 2006;138:1-9.

4. Dean DJ, Albelseth MK, Atanasiu P. The fluorescent antibody test. In: Meslin, FX, Kaplan MM, Koprowsky H, editors. Laboratory techniques in rabies. $4^{\text {th }}$ ed. Genebra: World Health Organization; 1996. p. 88-95.

5. Delpietro HA, Larghi OP, Russo RG. Virus isolation from saliva and salivary glands of cattle naturally infected with paralytic rabies. Prev Vet Med. 2001;48:223-8.

6. Diaz AM, Papo S, Rodriguez A, Smith, JS. Antigenic analysis of rabies-virus isolates from Latin American and the Caribbean. Zentralbl Veterinarmed B. 1994;41:153-60.

7. Hall TA. Bioedit: a user-friendly biological sequence alignment editor and analysis program for Windows 95/98/nt. Nucl Acids Symp Ser. 1999;41:95-8.

8. Kumar S, Tamura K, Jakbosen IE, Nei M. Mega 2: molecular evolutionary genetic analysis software. Tempe: Arizona State University; 2001

9. Koprowski H. The mouse inoculation test. In: Meslin FX, Kaplan MM, Koprowsky H, editors. Laboratory techniques in rabies. $4^{\text {th }}$ ed. Genebra: World Health Organization; 1996. p. 80-7.

10. Macedo CI, Carnieli Jr P, Brandão PE, Travassos da Rosa ES, Oliveira RN, Castilho JG, et al. Diagnosis of human rabies cases by Polymerase Chain Reaction of neck-skin samples. Braz J Infect Dis. 2006;10:341-5.

11. Ministério da Saúde. Fundação Nacional de Saúde. Guia de vigilância epidemiológica $5^{\text {a }}$ ed. Brasília: Ministério da Saúde; 2002. 2 v.

12. Ministério da Saúde. Protocolo para tratamento de raiva humana no Brasil. Epidemiol Serv Saúde. 2009;18:385-94

13. Rupprecht CE, Hanlon CA, Hemachudha T. Rabies re-examined. Lancet Infect Dis 2002;6:327-43.

14. Schneider MC, Belloto A, Adé MP, Hendrickx S, Leanes LF, Rodrigues MJF, et al. Current status of human rabies transmitted by dogs in Latin America. Cad Saúde Pública. 2007;23:2049-63. 
BRITO, M.G.; CHAMONE, T.L.; SILVA, F.J.; WADA, M.Y.; MIRANDA, A.B.; CASTILHO, J.G.; CARRIERI, M.L.; KOTAIT, I. \& LEMOS, F.L. - Antemortem diagnosis of human rabies in a veterinarian infected when handling a herbivore in Minas Gerais, Brazil. Rev. Inst. Med. Trop. São Paulo, 53(1): 39-44, 2011.

15. Willoughby RE, Tieves KS, Hoffman GM, Ghanayem NS, Amlie-Lefond CM, Schwabe MJ, et al. Survival after treatment of rabies with induction of coma. $\mathrm{N}$ Engl J Med. 2005;352:2508-14
16. World Health Organization. WHO Expert Consultation on Rabies. First report. Geneva: World Health Organization; 2005. 121p. (Technical Report Series; 931).

Received: 22 March 2010

Accepted: 22 November 2010 